\title{
STRES DAN KECEMASAN PADA DOSEN YANG MELAKSANAKAN KULIAH DARING PADA MASA PANDEMI COVID-19
}

\author{
Sugesti Aliftitah ${ }^{1}$, Nelyta Oktavianisya ${ }^{2}$ \\ Fakultas Ilmu Kesehatan Universitas Wiraraja \\ Email: sugesti@wiraraja.ac.id
}

\begin{abstract}
Online learning applied since March 2020, student had difficulties on phone signal, student poorly understood about the topic given by the lecturer. Problem faced by lecturer such as student didn't pay attention during online learning, and some of lecturers clueless with online learning app. The aim of this study was to represent anxiety and stress level of lecturers during online learning for pandemic covid 19 period. The design of this study was descriptive design. The Population in this study were all of lecturers as much as 168 lecturers with sample 63 lecturers. The variable of this study was anxiety and stress level of online learning lecturers. DASS Instrument was used to collect the data then analyzed by descriptive test The result of this study showed that respondent mostly on medium level of anxiety were 33 people $(52,4 \%)$ and the stress level of respondent mostly on medium level of stress werw 42 people (66,7\%). A lecturer expected to improve their coping mechanism in overcoming stress and anxiety during online learning for pandemic time. By proper stress management, it will increase lecturer work performances on this pandemic condition.
\end{abstract}

Keywords: Anxiety, Covid 19, Lecturers, Stress

\begin{abstract}
Abstrak: Pembelajaran daring mulai diterapkan sejak Maret 2020, muncul kendala mahasiswa mengalami kesulitan signal, mahasiswa kurang memahami topik yang disampaikan dosen. Kendala yang dihadapi dosen, seperti mahasiswa kurang memperhatikan saat belajar daring, dan beberapa dosen kurang memahami aplikasi-aplikasi yang bisa digunakan saat pembelajaran daring. Tujuan penelitian ini adalah untuk mengetahui gambaran kecemasan dan stres pada dosen yang melaksanakan kuliah daring pada masa pandemi COVID-19. Desain pada penelitian ini adalah deskriptif. Populasi dalam penelitian ini adalah seluruh dosen tetap sebanyak 168 dosen dengan sampel sebanyak 63 dosen. Variabel dalam penelitian ini adalah tingkat kecemasan dan stres pada dosen yang melaksanakan kuliah daring. Instrumen yang digunakan adalah DASS (Depression, anxiety and stress scale) dan kemudian data dianalisis dengan uji deskriptif. Hasil penelitian menunjukkan menunjukkan bahwa tingkat kecemasan responden sebagian besar berada pada tingkat sedang yaitu 33 orang $(52,4 \%)$ dan tingkat stres responden sebagian besar berada pada tingkat sedang yaitu 42 orang $(66,7 \%)$. Seorang dosen diharapkan dapat menambah wawasan tentang mekanisme koping dalam menangani stres dan kecemasan yang dialami selama mengajar daring di masa pandemi covid 19 dengan manajemen stres yang tepat akan meningkatkan kinerja dosen dalam kondisi pandemi ini.
\end{abstract}

Kata kunci: Covid 19, Dosen, Kecemasan, Stres

\section{PENDAHULUAN}

Kondisi

mengharuskan mandemik yang

Physical distancing berimbas universitas sebagai institusi yang bergerak di bidang pendidikan. Universitas adalah bagian dari fasilitas dan tempat yang memungkinkan berkumpulnya mahasiswa, dosen, tenaga kependidikan dan civitas akademika yang lain. Menteri Pendidikan dan Kebudayaan (Mendikbud), menerbitkan Surat Edaran Nomor 4 Tahun 2020 tentang Pelaksanaan Pendidikan Dalam Masa Darurat Coronavirus Disease (COVID-19) dimana kegiatan belajar dilaksanakan dari rumah secara daring. Pelaksanaan pembalajaran daring mulai diterapkan sejak Maret 2020, dalam waktu 10 bulan yang telah dilewati mulai muncul kendala-kendala yang ditemui saat pembelajaran daring baik dari mahasiswa dan dosen, mahasiswa mengalami kesulitan signal terutama mahasiswa yang berasal dari kepulauan, mahasiswa kurang memahami topik yang disampaikan dosen. Kendala yang dihadapi dosen, seperti mahasiswa kurang memperhatikan saat belajar daring, dan beberapa dosen kurang memahami aplikasi-aplikasi yang bisa digunakan saat pembelajaran daring. Hal ini menimbulkan stres dan kecemasan tersendiri bagi dosen yang melaksanakan perkuliahan daring (Kemendikbud, 2020).

Menurut WHO Per Senin (10/6/2020) 06:32 WIB, total kasus COVID-19 di dunia 
terkonfirmasi sebanyak 7.311.062 (7,3 juta) kasus hingga Rabu. Dari jumlah tersebut, sebanyak 3.594.227 (3,5 juta) pasien telah sembuh, 412.993 orang meninggal dunia. Kasus aktif hingga saat ini tercatat sebanyak 3.303.842 dengan rincian 3.249.902 pasien dengan kondisi ringan dan 53.940 dalam kondisi serius. Di Indonesia Jumlah kasus baru total kasus positif: 32.033 orang, total pasien dirawat: 19.246 orang $(60,1$ persen $)$ total pasien sembuh: 10.904 orang (34 persen) Total pasien meninggal: 1.883 jiwa (5,9 persen), total PDP masih diawasi: 14.010 orang, total ODP masih dipantau: 38.791 orang. Pemprov Jatim melalui halaman resminya infocovid19.jatimprov.go.id Pada Selasa, 9 Juni 2020, terdapat 25.801 orang dalam pemantauan (ODP), 7.579 pasien dalam pengawasan (PDP), 6.518 dinyatakan positif COVID-19, dan yang sembuh 1.681 orang. Sementara itu, total pasien meninggal dunia 530 orang (Bramasta, 2020).

Kecemasan timbul akibat wabah virus corona yang sedang melanda dunia saat ini. Berita yang disampaikan terus menerus, kabar yang tidak jelas asalnya serta adanya beribu tulisan mengenai corona di internet, terutama media sosial menambah kekhawatiran terhadap kebenaran dari informasi tersebut. Keberadaan virus ini menyebabkan munculnya kebijakan-

\section{METODE PENELITIAN}

Dalam penelitian
mendeskripsikan data-data penelitian
tentang stres dan kecemasan pada dosen
yang melaksanakan kuliah daring pada
masa pandemi COVID-19. Populasi dalam
penelitian ini adalah seluruh dosen tetap di
salah satu universitas sebanyak 168 dosen.
Sampel dalam penelitian ini sebanyak 63
dosen. Teknik sampling yang digunakan

\section{HASIL PENELITIAN}

Dosen yang menjadi responden pada penelitian ini sebanyak 63 orang. Data diperoleh dari hasil pengumpulan data dengan menggunakan kuesioner yang kebijakan baru dari pemerintah untuk pendidikan, pemberlakuan pembelajaran daring diterapkan disemua tingkat lembaga pendidikan (YangID et al., 2021).

Penyampaian pembelajaran secara daring memberikan dampak positif dapat mencegah penyebaran virus corona, namun di sisi lain dampak dari pembelajaran daring yaitu sangat tergantung pada kondisi sinyal handphone atau internet, para guru dan dosen dituntut untuk bisa mengaplikasikan beberapa aplikasi yang jarang digunakan saat pelajaran luring, presentasi atau materi yang disampaikan harus menarik, namun tak jarang mahasiswa kurang memperhatikan saat pembelajaran daring, hal -hal tersebut yang bisa menimbulkan stres dan kecemasan pada para pengajar yang melakukan pembelajaran secara daring (Anisa et al., 2020; Sadikin \& Hamidah, 2020).

Pemberian pelatihan pengenalan aplikasi-aplikasi yang bisa digunakan saat pembelajaran daring atau pelatihan pembuatan materi atau metode pembelajaran yang menarik bagi para pengajar akan sangat membantu mengurangi kecemasan dan stres yang mungkin dialami oleh para pengajar. Dan diperlukan sistem pembelajaran yang memungkinkan pengajar untuk menilai kehadiran secara menyeluruh dari mahasiswa saat pembelajaran daring.

adalah simple random sampling dengan 2 variabel yang diukur yaitu stres dan kecemasan. Stres dan kecemasan diukur dengan instrument DASS (Clark \&Watson.1991) yang sudah teruji validitas dan reabilitasnya. Uji statistik deskriptif ini digunakan untuk mendapatkan gambaran distribusi frekuensi masing-masing variabel penelitian yaitu stres dan kecemasan pada dosen yang melaksanakan kuliah daring pada masa pandemi COVID-19.

disebarkan secara online dengan google forms. Karakteristik responden berupa data umum yang meliputi umur, jenis kelamin, lama bekerja, jabatan, jumlah SKS, jumlah tatap muka dan metode pembelajaran yang ditunjukkan pada tabel 1. 
Tabel 1. Karakteristik Responden

\begin{tabular}{|c|c|c|}
\hline Karakteristik Responden & $\Sigma$ & $\%$ \\
\hline \multicolumn{3}{|l|}{ Umur } \\
\hline $32-34$ & 25 & 39,7 \\
\hline $35-37$ & 7 & 11,1 \\
\hline $41-43$ & 22 & 34,9 \\
\hline $44-46$ & 6 & 9,5 \\
\hline $47-49$ & 3 & 4,8 \\
\hline \multicolumn{3}{|l|}{ Jenis Kelamin } \\
\hline Perempuan & 42 & 66,7 \\
\hline Laki-laki & 21 & 33,3 \\
\hline \multicolumn{3}{|l|}{ Lama Bekerja } \\
\hline$<1$ Tahun & 2 & 3,2 \\
\hline 2-5 Tahun & 18 & 28,6 \\
\hline$>5$ Tahun & 43 & 68,3 \\
\hline \multicolumn{3}{|l|}{ Jabatan } \\
\hline Dosen Biasa & 54 & 85,7 \\
\hline Dosen dengan Tugas Tambahan & 9 & 14,3 \\
\hline \multicolumn{3}{|l|}{ Jumlah SKS } \\
\hline 3-7 SKS & 11 & 17,5 \\
\hline 8 SKS & 50 & 79,4 \\
\hline$>8 \mathrm{SKS}$ & 2 & 3,2 \\
\hline \multicolumn{3}{|l|}{ Jumlah TM } \\
\hline 1-4 TM/ Minggu & 50 & 79,4 \\
\hline 5-10 TM/ Minggu & 13 & 20,6 \\
\hline \multicolumn{3}{|l|}{ Metode Pembelajaran } \\
\hline Google Classroom & 25 & 39,7 \\
\hline WhatsApp & 20 & 31,7 \\
\hline Zoom Meeting & 13 & 20,6 \\
\hline Google meet & 1 & 1,6 \\
\hline Lainnya & 4 & 6,3 \\
\hline
\end{tabular}

Tabel 1. menunjukkan bahwa umur responden hampir setengahnya berumur 32-34 tahun yaitu 25 orang (39,7\%). Responden sebagian besar responden berjenis kelamin perempuan sebanyak 42 orang $(66,7 \%)$. Lama bekerja responden sebagian sebesar $>5$ tahun sebanyak 43 orang (68,3\%). Hampir seluruhnya responden adalah dosen biasa yaitu sebanyak 54 orang $(85,7 \%)$. Jumlah SKS mata kuliah yang diampu di semester ganjil tahun akademik 2020-202, hampir seluruhnya yaitu 8 SKS sebesar 50 orang $(79,4 \%)$. Jumlah tatap muka dalam seminggu di Semester Ganjil Tahun Akademik 2020-2021 hampir setengahnya 1-4 TM/ Minggu yaitu 50 orang $(79,4 \%)$. Metode pembelajaran daring yang paling sering digunakan di Semester Ganjil Tahun Akademik 2020-2021 hampir setengahnya menggunakan Google Classroom dan WhatsApp yaitu masing-masing 25 orang $(39,7 \%)$ dan 20 orang $(31,7 \%)$.

Tabel 2. Tingkat Kecemasan pada Responden di Univeristas Wiraraja tahun 2021

\begin{tabular}{ccc}
\hline Tingkat Kecemasan & Frekuensi & Persentase (\%) \\
\hline Normal & 13 & 20,6 \\
Ringan & 17 & 27,0 \\
Sedang & 33 & 52,4 \\
\hline Jumlah & 63 & 100 \\
\hline
\end{tabular}


Tabel 2 menunjukkan tingkat kecemasan responden sebagian besar berada pada tingkat sedang yaitu 33 orang $(52,4 \%)$.

Tabel 3. Tingkat Stres pada Responden di Univeristas Wiraraja tahun 2021

\begin{tabular}{ccc}
\hline Tingkat Stres & Frekuensi & Persentase (\%) \\
\hline Normal & 12 & 19,0 \\
Ringan & 9 & 14,3 \\
Sedang & 42 & 66,7 \\
\hline Jumlah & 63 & 100 \\
\hline
\end{tabular}

Tabel 3 menunjukkan tingkat stres responden sebagian besar berada pada tingkat sedang yaitu 42 orang $(66,7 \%)$.

\section{PEMBAHASAN}

\section{Kecemasan}

Kecemasan merupakan rasa khawatir yang tidak jelas dan meluas, yang berhubungan dengan perasaaan yang tidak pasti dan tidak berdaya (Annisa \& Ifdil, 2016; Mukholil, 2018). Sedangkan menurut Sutejo (2017) dan Warouw (2018), Kecemasan (ansietas) ialah suatu perasaan tidak santai yang samar-samar karena adanya ketidaknyamanan atau rasa takut yang disertai suatu respon. Kecemasan juga dapat pula diterjemahkan sebagai suatu perasaan takut akan terjadinya sesuatu yang disebabkan oleh antisipasi bahaya dan merupakan sinyal yang membantu individu untuk bersiap mengambil tindakan untuk menghadapi bahaya (Sutejo, 2018; Warouw et al., 2018 dan Asyura et al., 2021).

Pada penelitian ini, didapatkan bahwa tingkat kecemasan Dosen yang Melaksanakan Kuliah Daring pada Masa Pandemi COVID-19 sebagian besar berada pada tingkat sedang. Pada kondisi ini individu berfokus pada hal yang penting dan mengesampingkan yang lain. Pada tingkat ini lapangan persepsi terhadap lingkungan menurun. Individu mengalami perhatian yang tidak selektif namun dapat berfokus pada lebih banyak area jika diarahkan untuk melakukannya (Stuart dalam Annisa \& Ifdil, 2016; Guan et al., 2021). Menurut Videbeck dalam Fauziah (2018), respons dari kecemasan sedang adalah sebagai berikut: a) Respon fisik menunjukkan adanya ketegangan otot sedang, tanda-tanda vital meningkat, pupil dilatasi, mulai berkeringat, sering mondarmandir, memukul tangan, dan suara berubah (bergetar, nada suara tinggi, sakit kepala, pola tidur berubah, dan nyeri punggung), b) Respons kognitif menunjukkan lapang persepsi menurun, tidak perhatian secara selektif, fokus terhadap stimulus meningkat, rentang perhatian menurun, penyelesaian masalah menurun, dan pembelajaran terjadi dengan memfokuskan, c) Respons emosional menunjukkan ketidaknyamanan, mudah tersinggung, kepercayaan diri goyah, tidak sabar, dan sedih (Namirotu et al., 2018). Hasil penelitian ini sejalan dengan penelitian aydin dan ustuk (2020), bahwa tenaga pengajar mengalami kecemasan sedang (moderate) karena ketertarikan siswa pada mata pelajarannya yang kurang.

Kondisi cemas pada dosen yang melaksanakan pembelajaran daring dapat disebabkan oleh beberapa faktor. maturitas individu, tipe kepribadian, tingkat pendidikan, sosial budaya, potensi stres, serta lingkungan. Menurut penelitian ini, hampir setengah responden berusia 32-34 tahun, pada usia tersebut individu memiliki kematangan diri (selfmaturity) yang baik, memiliki selfcontrol dan selfdirection yang baik sehingga kecemasan berada di tingkat sedang. Individu dengan selfmaturity yang baik, akan dengan mudah menghadapi stresor yang dihadapi. Stuart G.W \& Laraia M.T (2007) menyatakan bahwa maturitas atau kematangan individu akan mempengaruhi kemampuan koping mekanisme seseorang sehingga individu yang lebih matur sukar mengalami kecemasan karena individu mempunyai kemampuan adaptasi yang lebih besar terhadap kecemasan dibandingkan usia yang belum matur. 
Dampak pembelajaran daring tidak hanya dialami mahasiswa atau anak didik, dosen sebagai pendidik pun merasakannya. Dosen dituntut mampu menyampaikan materi dengan media yang mungkin jarang digunakan saat pertemuan di kelas. Dosen juga dituntut untuk menyampaikan materi yang menarik agar mahasiswa tidak bosan saat proses belajar mengajar. Berdasarkan penelitian ini, didapatkan bahwa hampir setengah responden menggunakan Google Classroom dan WhatsApp sebagai media pembelajaran. Dua media ini relatif lebih mudah dan lebih murah, namun tampilan kurang menarik, dan beberapa mahasiswa menyalahgunakan dan kurang fokus terhadap materi yang diberikan, sehingga pada akhirnya menimbulkan kecemasan tersendiri bagi dosen yang memberikan materi.

\section{Stres}

Stres adalah gangguan pada tubuh
dan pikiran yang disebabkan oleh perubahan dan tuntutan kehidupan (Mundung et al., 2019). Menurut Charles D. Speilberger dalam Donsu (2017) dan Gaol (2016), menyatakan bahwa stres merupakan tuntutan-tuntutan eksternal yang dialami oleh orang, contohnya objek yang berada dalam suatu lingkungan atau suatu stimulus yang secara obyektif merupakan bahaya. Stres bisa juga diartikan sebagai tekanan, ketegangan, gangguan yang membuat seseorang tidak senang dan asalnya dari luar diri seseorang (Gaol, 2016; Donsu, 2019; Morales, 2021).

Berdasarkan penelitian didapatkan tingkat stres responden sebagian besar berada pada tingkat sedang. Stres sedang berlangsung lebih lama daripada stres ringan. Penyebab stres sedang yaitu situasi yang tidak terselesaikan dengan rekan, anak yang sakit, atau ketidak hadiran yang lama dari anggota keluarga. Ciri-ciri stres sedang yaitu sakit perut, otot-otot terasa tengang, perasaan tegang, gangguan tidur, badan terasa ringan. Sejalan dengan penelitian Arianandha (2021) yang meneliti tentang beban kerja mental dan dosen terhadap pemenuhan kewajiban Tri Dharma Perguruan Tinggi di Masa Pandemi Covid
19, dengan hasil $64 \%$ responden masuk kedalam kategori stress sedang.

Menurut Budiwati (2016), beratnya tuntutan tugas Dosen dapat mengakibatkan stres apabila kurang mampu beradaptasi keinginan dengan kenyataan yang ada, baik kenyataan yang ada didalam maupun kenyataan yang ada diluar dirinya. Segala macam bentuk stres, pada dasarnya disebabkan oleh kurang mengertinya manusia akan keterbatasannya sendiri. Ketidakmampuan untuk melawan keterbatasan inilah yang akan menimbulkan frustasi, konflik, gelisah dan rasa bersalah (Budiwati, 2016). Beban kerja dosen dalam penelitian ini dapat dilihat dari jumlah tatap muka dalam seminggu, jumlah SKS mata kuliah yang diampu dan jabatan yang diampu dosen.

Dari hasil penelitian didapatkan bahwa hampir seluruhnya responden merupakan dosen tetap biasa tanpa jabatan, dengan beban SKS dalam satu semester hampir seluruhnya 8 SKS dan tatap muka dalam seminggu hampir setengah responden 1- 4 kali tatap muka per minggu. Hal ini menyebabkan stres yang dialami responden masih dalam kategori sedang. Namun kondisi stres sedang yang tidak tertangani menimbulkan dampak yang signifikan terhadap kinerja dosen, pada tingkat stres yang rendah kinerja dosen rendah. Pada kondisi ini dosen tidak memiliki tantangan dan muncul kebosanan karena under stimulation. Seiring dengan kenaikan tingkat stres sampai pada suatu titik optimal, maka akan menghasilkan kinerja yang baik. Kondisi ini disebut tingkat stres yang optimal. Pada tingkat stres yang optimal ini akan menciptakan ide-ide yang inovatif, antusiasme, dan output yang konstruktif. Pada tingkat stres yang sangat tinggi kinerja dosen juga rendah. Pada kondisi ini terjadi penurunan kinerja. Tingkat stres yang berlebihan akan menyebabkan dosen dalam kondisi tertekan, karena tidak mampu lagi mengatasi tugas yang berat.

Keterbatasan Penelitian ini adalah, kondisi pandemik sudah berlangsung cukup lama, sehingga dosen atau tenaga pengajar sedikit banyak sudah mampu beradaptasi dengan kondisi "new normal". 


\section{KESIMPULAN DAN SARAN}

Kecemasan pada Dosen yang melaksanakan kuliah daring pada Masa Pandemi COVID-19 sebagian besar berada pada tingkat sedang. Tingkat Stres pada Dosen yang Melaksanakan Kuliah Daring pada Masa Pandemi COVID-19 sebagian besar berada pada tingkat sedang.

Responden diharapkan dapat menambah wawasan dan dapat

\section{DAFTAR PUSTAKA}

Anisa, Lailatull, U., Indrawati, Fauziah, \& Yuni, L. E. (2020). Hand Sanitizer Berbahan Daun Binahong Sebagai Antimikroba Untuk Satu Langkah Pencegahan Penularan Covid-1. PROCEEDING KKN BMC UNNES, 1-7.

Annisa, D. F., \& Ifdil. (2016). Konsep Kecemasan (Anxiety) pada Lanjut Usia (Lansia). Konselor, 5(2), 93-99.

Asyura, M. M. A. Z., Ar-Rizq, M. F., \& Siagian, R. M. (2021). Psychosocial Impact Analysis: Depression and Anxiety During the COVID-19 Pandemic Amongst Students. Jurnal IImiah Mahasiswa Kedokteran Indonesia, 8(3), 174-188.

Bramasta, D. B. (2020). Update Virus Corona di Dunia 10 Juni: 7,3 Juta Orang Terinfeksi, Klarifikasi Pakar WHO. Kompas.

Budiwati, H. (2016). Identifikasi Sumber Stres Tenaga Pengajar Dan Pengaruhnya Terhadap Kinerja Dosen Di Stie Widya Gama Lumajang. Jurnal Penelitian IImu Ekonomi WIGA, 6(1), 27-35.

Donsu, J. D. T. (2019). Psikologi keperawatan. Pustaka Baru Press.

Gaol, N. T. L. (2016). Teori Stres: Stimulus, Respons, dan Transaksional. Buletin Psikologi, 24(1), 1-11.

Guan, J., Wu, C., Wei, D., Xu, Q., Wang, J., Lin, H., Wang, C., Mao, \& Zhenxing. (2021). Prevalence and Factors for Anxiety during the COVID-19 Pandemic among College Students in China. Int. J. Environ. Res. Public Health 2021, 18(4974).

Kemendikbud. (2020). Mendikbud Terbitkan SE tentang Pelaksanaan Pendidikan menerapkan mekanisme koping dalam menangani stres dan kecemasan yang dialami selama mengajr daring di masa pandemik COVID-19 dan dapat menerapkan.

Institusi dapat memberikan skrining bagi responden sehingga dapat menangani stres dan kecemasan secara dini.

dalam Masa Darurat Covid-19. Kementerian Pendidikan Dan Kebudayaan.

Morales, F. M. (2021). Fear, Stress, Resilience and Coping Strategies during COVID-19 in Spanish University Student. Sustainability, 13(5824), 1-19.

Mukholil. (2018). Kecemasan Dalam Proses Belajar. Jurnal Eksponen, 8(1), 1-8.

Mundung, G. J., Kairupan, B. H. R., \& Kundre, R. (2019). Hubungan Mekanisme Koping Dengan Stres Kerja Perawat Di Rsu Gmim Bethesda Tomohon. E-Journal Keperawatan (e-Kp), 7(1), 1-6.

Namirotu, F., Rafiyah, I., \& Solehati, T. (2018). Parent's Anxiety Towards Juvenile Deliquency Phenomenon In Bandung Indonesia. NurseLine Journal, 3(2), 52-59.

Nursalam. (2015). Metodologi Penelitian IImu Keperawatan. Salemba Medika.

Özdemir, Ö. (2020). Coronavirus Disease 2019 (COVID-19): Diagnosis and Management. Erciyes Med J, 42(3), 242-247.

Sadikin, A., \& Hamidah, A. (2020). Pembelajaran Daring di Tengah Wabah Covid-19. Jurnal IImiah Pendidikan Biologi, 6(2), 214-224.

Setiawan, E. (2020). Strategi Pengembangan Produk Jmabu Kristal di Era New Normal. Jurnal Pembelajaran Pemberdayaan Masyarakat, 1(4), 323-327.

Susilo, A., Rumende, Martin, C., Pitoyo, Wicaksono, C., Santoso, Djoko, W., Mira, Y., Sinto, H., Robert, Singh, Gurmeet, Nainggolan, Leonard, Nelwan, E. J., Chen, Khie, L., Widhani, A., Wijaya, E., ... 
Yunihastuti, E. (2020). Coronavirus Disease 2019: Review of Current Literatures. Jurnal Penyakit Dalam Indonesia, 7(1), 45-67.

Sutejo. (2018). Keperawatan Jiwa, Konsep dan Praktik Asuhan Keperawatan Kesehatan Jiwa: Gangguan Jiwa dan Psikososial. Pustaka Baru Press.

Warouw, H. J., Tambuwun, S., \& Pandeirot, G. M. (2018). Dampak Edukasi Terhadap Kecemasan Pasien Pra Operasi Katarak Di Rumah Sakit Mata Provinsi Sulawesi Utara. JUIPERDO, 6(1), 23-31.
YangID, C., Chen, A., \& Chen, Y. (2021). College students' stress and health in the COVID-19 pandemic: The role of academic workload, separation from school, and fears of contagion. PLOS ONE, 16(2), 1-16.

Yao, T.-T., Qian, J.-D., Zhu, W.-Y., Wang, Y., \& Wang, G.-Q. (2020). A systematic review of lopinavir therapy for SARS coronavirus and MERS coronavirus-A possible reference for coronavirus disease-19 treatment option. J Med Virol, 92(6), 556-563. 